\title{
Ex-situ Biodegradation of petroleum hydrocarbons using Alcanivorax borkumensis enzymes
}

Article in Biochemical Engineering Journal · January 2018

DOI: 10.1016/j.bej.2018.01.014

CITATIONS

0

4 authors, including:

\section{Sarra Magdouli}

Institut National de la Recherche Scientifique 15 PUBLICATIONS 118 CITATIONS

SEE PROFILE

\section{Satinder Kaur Brar}

Institut National de la Recherche Scientifique 230 PUBLICATIONS $\quad 3,462$ CITATIONS

SEE PROFILE
READS

26

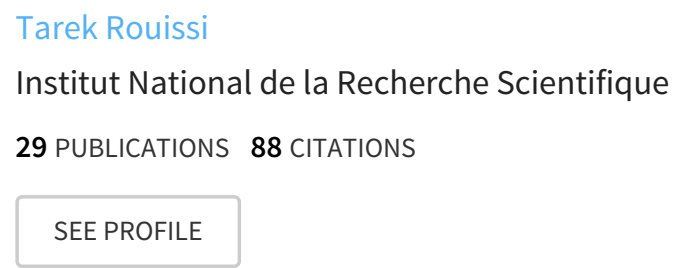

Some of the authors of this publication are also working on these related projects: 


\section{Accepted Manuscript}

Title: Ex-situ Biodegradation of petroleum hydrocarbons using Alcanivorax borkumensis enzymes

Authors: Tayssir Kadri, Sara Magdouli, Tarek Rouissi, Satinder Kaur Brar

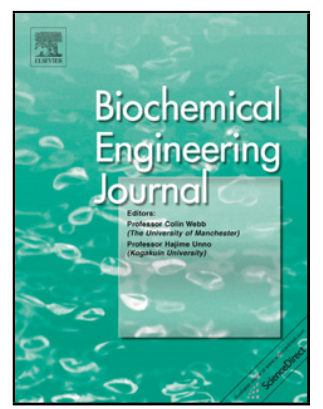

PII:

S1369-703X(18)30015-9

DOI: https://doi.org/10.1016/j.bej.2018.01.014

Reference: BEJ 6863

To appear in:

\section{Biochemical Engineering Journal}

Received date:

7-9-2017

Revised date: $19-12-2017$

Accepted date:

$13-1-2018$

Please cite this article as: Tayssir Kadri, Sara Magdouli, Tarek Rouissi, Satinder Kaur Brar, Ex-situ Biodegradation of petroleum hydrocarbons using Alcanivorax borkumensis enzymes, Biochemical Engineering Journal https://doi.org/10.1016/j.bej.2018.01.014

This is a PDF file of an unedited manuscript that has been accepted for publication. As a service to our customers we are providing this early version of the manuscript. The manuscript will undergo copyediting, typesetting, and review of the resulting proof before it is published in its final form. Please note that during the production process errors may be discovered which could affect the content, and all legal disclaimers that apply to the journal pertain. 


\section{Ex-situ Biodegradation of petroleum hydrocarbons using Alcanivorax borkumensis enzymes}

Tayssir Kadri ${ }^{1}$, Sara Magdouli ${ }^{1}$, Tarek Rouissi ${ }^{1}$ and Satinder Kaur Brar ${ }^{1 *}$

${ }^{1}$ INRS-ETE, Université du Québec, 490, Rue de la Couronne, Québec, Canada G1K 9A9.

*Corresponding author: Tel: + 418654 3116; Fax: + 418654 2600; E-mail:

satinder.brar@ete.inrs.ca

\section{Graphical abstract}

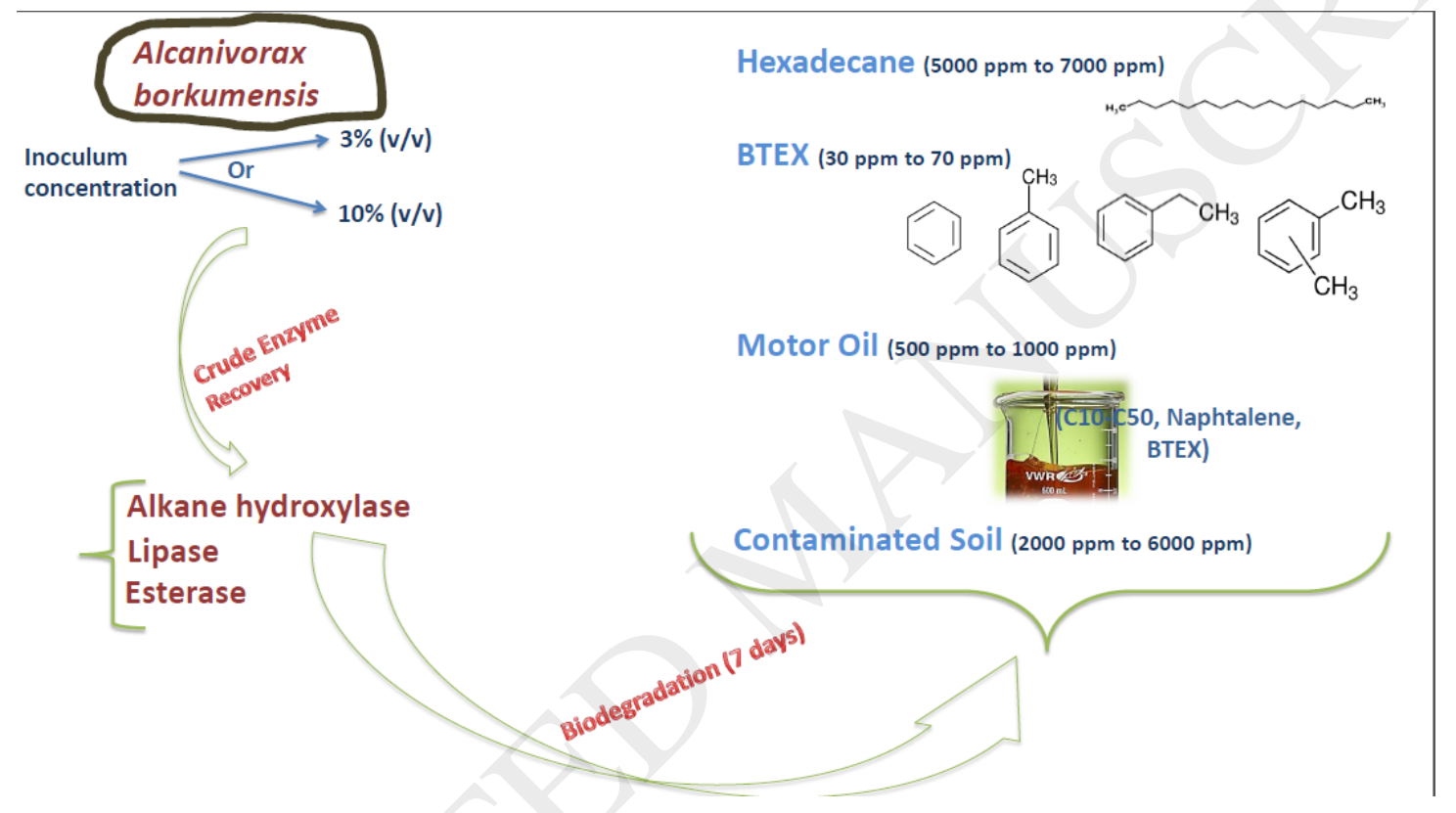

\section{Highlights}

- Production of enzymes by Alcanivorax borkumensis is studied.

- Biodegradation of different petroleum hydrocarbon substrates is investigated.

- Enzymes efficiency depends on the inoculum and hydrocarbons concentration. 


\begin{abstract}
Bioremediation for degradation of hydrocarbons is a widely used alternative for the recovery of contaminated sites. The current study aimed to use Alcanivorax borkumensis crude enzyme preparation as an agent for enhanced microbial hydrocarbons biodegradation in contaminated water and soil. The inoculum and hydrocarbons concentration have a remarkable effect on the biodegradation with the crude enzymes. The high enzymatic production reaching 145.71 $\mathrm{U} / \mathrm{mg}$ for alkane hydroxylase, $3628.57 \mathrm{U} / \mathrm{mg}$ for lipase and $2200 \mathrm{U} / \mathrm{mg}$ for esterase led to a significant degradation efficiency of the different concentrations of petroleum hydrocarbon substrates reaching $73.75 \%$ for $5000 \mathrm{ppm}$ of hexadecane, $82.80 \%$ for $1000 \mathrm{ppm}$ of motor oil, $64.70 \%$ for $70 \mathrm{ppm}$ of BTEX and $88.52 \%$ for $6000 \mathrm{ppm}$ of contaminated soil. The study suggested that Alcanivorax borkumensis is a potential hydrocarbon-degrading bacterium with higher enzymatic capacities for bioremediation of hydrocarbon-polluted environment.
\end{abstract}

Keywords: Biodegradation; Petroleum Hydrocarbons; Alcanivorax borkumensis; Enzymes Production

\title{
1. Introduction
}

Petroleum is the most cost-effective energy source in the current global economy. Its widespread and extensive use has led to serious ecological problems and severe disruption of the ecological balance [1].

The removal of petroleum-hydrocarbons by means of mechanical and physical methods is used as a primary response during oil spill. However, the efficiency of mechanical removal is limited. Bioremediation has been proven to be successful and eco-friendly in the mineralization and removal of petroleum hydrocarbon contaminants in different habitats, such as water and soil [2-4]. Some recently characterized bacterial species are highly specialized for hydrocarbon degradation. These species are called hydrocarbonoclastic bacteria, and they play a key role in the removal of hydrocarbons from polluted environments [5-8] 
- Importantly, Alcanivorax borkumensis, a marine bacterium that can assimilate various hydrocarbons $[6,9,10]$. Alcanivorax borkumensisis present in non-polluted seawater in low numbers; however, their number can increase as a result of an oil spill, and they are believed to play an important role in the natural bioremediation of oil spills worldwide [13-15]. Moreover, Alcanivorax borkumensis is able to produce a glucolipid biosurfactant [14,15] which may enhance the bioavailability of hydrocarbons by either increasing apparent hydrocarbon solubility in the aqueous phase or by expanding the contact surface area due to emulsification [16].

A. borkumenis genome has been completely sequenced and hence leading to a better understanding of the cellular biology of hydrocarbons metabolism [17]. Many genes encoding for enzymes initiating the degradation of these hydrocarbons have been detected [10-12]. However, very few biochemical studies have been carried out on the enzymatic effectiveness of this autochthonous hydrocarbonoclastic bacteria in oil spill remediation [20]. Therefore, understanding the biochemical pathway is a key feature in environmental bioremediation. With this aim, the production of alkane hydroxylase (EC: 1.14.15.3), lipase (EC: 1.3.3.-) and esterase (EC: 1.3.3.-) was investigated. The A. borkumensis alkane hydroxylase system is able to degrade a large range of alkanes up to $\mathrm{C} 32$ and branched aliphatic, as well as isoprenoid hydrocarbons, alkylarenes and alkylcycloalkanes. This spectrum is much larger based on knowledge about alkane hydroxylase complexes. This makes the choice of alkane hydroxylase of a unique importance. Furthermore, A. borkumensis genome includes 11 genes coding for different lipases/esterases of unknown specificity. Two of these esterases were purified and functionally characterized. They showed generous enzymatic activity that is up to two orders of magnitude better than common esterases, have a large substrate spectrum, exceptional enatioselectivity and chemical resistance, which provides them a competitive advantageous over other esterases from other microorganisms and other enzymes for the 
resolution of chiral mixtures in biocatalysis [17]. Other than the extensive production by $A$. borkumensis, lipase played an important role in oily hydrocarbons biodegradation. In fact, lipase activity has been used as biochemical and biological parameter for testing hydrocarbon degradation and it is an excellent indicator to monitor the decontamination of a hydrocarbon polluted site [21].

The present work aims to study the capacity of crude enzymes produced by Alcanivorax borkumensis, to degrade petroleum hydrocarbons represented by hexadecane with a concentration varying from $5000 \mathrm{mg} / \mathrm{L}$ to $7000 \mathrm{mg} / \mathrm{L}$, BTEX with a concentration of the six compounds varying from $30 \mathrm{mg} / \mathrm{L}$ to $70 \mathrm{mg} / \mathrm{L}(1: 1: 1: 1: 1: 1)$, motor oil with a concentration varying from $500 \mathrm{mg} / \mathrm{L}$ to $1000 \mathrm{mg} / \mathrm{L}$ and contaminated soil with a concentration of total petroleum hydrocarbons varying from $2000 \mathrm{mg} / \mathrm{L}$ to $6000 \mathrm{mg} / \mathrm{L}$. these concentrations were chosen depending on soil characterization and PAHs, BTEX and C10-C50 content. Also we varied the inoculum concentration from $3 \%(\mathrm{v} / \mathrm{v})$ to $10 \%(\mathrm{v} / \mathrm{v})$ for higher enzyme production and measured alkane hydroxylase, lipase and esterase specific activity during the degradation process when using the highest petroleum hydrocarbon substrate concentration (7000 ppm for hexadecane, $70 \mathrm{ppm}$ for BTEX, $1000 \mathrm{ppm}$ for motor oil and $6000 \mathrm{ppm}$ for the contaminated soil). The biodegradation was carried out during 3 days for BTEX and 7 days for the remaining substrates.

\section{Materials and methods}

All chemical reagents of highest purity, such as hexadecane, BTEX (Benzene, Toluene, Ethylene, Xylene), NADPH (nicotinamide adenine dinucleotide phosphate) and DMSO (Dimethyl sulfoxide) among others, were procured from Sigma-Aldrich, Fisher scientific or VWR (Mississauga, Ontario, Canada). The strain, Alcanivorax borkumensis was purchased from DSMZ (Braunschweig, Germany).

\subsection{Soil and motor oil characteristics}


The contaminated soil used in this study was provided by TechnoRem Inc from a confidential site in Quebec. This soil was chosen due to its intense contamination with total petroleum hydrocarbons. The soil comprised $59 \%$ of $1 \mathrm{~mm}$ sized particles, $38 \%$ of particles with a size range between $250 \mu \mathrm{m}$ and $500 \mu \mathrm{m}$ and $3 \%$ of very fine particles with a size less than 250 $\mu \mathrm{m}$.

The chemical characteristics of the heavily contaminated soil used during this study are presented in Tables 1, 2 and 3.

Total solids (TS) and moisture content were measured using the protocol 2540B of Federation et al. [22] which consists of heating the clean dish to $103 \pm 1$ to $105 \pm 1{ }^{\circ} \mathrm{C}$ for $1 \mathrm{~h}$. Later, it was stored and cooled in the desiccator. And finally, it was weighed immediately before use. To determine the elemental concentration of carbon and nitrogen, the sample was first dried at $60 \pm 1{ }^{\circ} \mathrm{C}$ for $8 \mathrm{~h}$ and placed into a glass vial. Two sub-samples (2-3 mg each) were analyzed using a Leco-932 CHNS Analyzer in CHN mode. In CHN mode, samples are combusted in the presence of pure $\mathrm{O}_{2}$ and the combustion gases are measured to determine initial elemental concentrations of $\mathrm{C}, \mathrm{H}$ and $\mathrm{N}$.

Oil content was determined by adding $n$-hexane to the soil $(1: 1 \mathrm{w} / \mathrm{v})$ and then centrifuging at $10,000 \times \mathrm{g}$ for 30 minutes to recover the pellet. Once again, $\mathrm{n}$-hexane was added to the pellet $(1: 1 \mathrm{w} / \mathrm{v})$ and then centrifuged at the same speed and time to recover the pellet. Finally, $\mathrm{n}-$ hexane was dried at room temperature and the oil content (supernatant) was weighed. Metals content was determined using inductively coupled plasma optical emission spectrometry (ICP-OES). Samples digestion was fulfilled following the method MENVIQ.89.12/213.Mét 1.3. All the analyses were performed in triplicates.

The method used to determine the PAHs is MA. 400 - HAP 1.1, which consists of: extracting PAHs using dichloromethane or hexane after adding recovery standards ("surrogates"). Later, the extract was concentrated to a small volume under a nitrogen stream and purified on a 
silica gel-alumina column. The final volume of purified extract was concentrated to meet the target detection limits. Finally, the extract was concentrated and then analyzed by chromatography gas phase coupled to a mass spectrometer (GC-MS) operating in the mode selective ion acquisition ("SIM") was used. The method used to determine the C10-C50 was MA. 400 - HYD. 1.1, which consists of extracting aqueous samples with hexane using a mechanical stirrer. Solid samples are first dried with acetone, and then extracted with hexane with the aid of an extraction system "mixer painting". As for organic liquids, they are directly diluted in hexane. Thereafter, silica gel is added to the extract to adsorb polar substances and then the supernatant was analyzed by gas chromatography coupled to flame ionization detector.

The composition of motor oil in this study comprised: $69.8 \mathrm{mg} / \mathrm{L}$ of C10-C50, $1.83 \mathrm{mg} / \mathrm{L}$ of naphthalene, $\leq 44 \mathrm{mg} / \mathrm{L}$ of benzene, $\leq 30 \mathrm{mg} / \mathrm{L}$ of toluene, $\leq 44 \mathrm{mg} / \mathrm{L}$ of ethyl-benzene and $\leq$ $84 \mathrm{mg} / \mathrm{L}$ of xylene.

\subsection{Bacterial strain}

Aerobic bacterial strain, Alcanivorax borkumensis SK2 (DSM 11573) which has the capability to degrade petroleum hydrocarbons was used in all the experiments in this study. The strain was stored at $4{ }^{\circ} \mathrm{C}$ on agar plates coated with a film of hexadecane.

\subsection{Culture conditions}

Initial culture of A. borkumensis strain was grown aerobically in batch culture in $250-\mathrm{mL}$ Erlenmeyer flasks for $72 \mathrm{~h}$ at $30 \pm 1{ }^{\circ} \mathrm{C}$ and $150 \mathrm{rpm}$ in synthetic sea water medium SM1 in order to mimic the conditions of an oil spill in the environment (high carbon concentration and nitrogen limitation). This medium was supplemented each time with a different substrate used as a sole carbon and energy source: 3\% hexadecane, 3\% motor oil and 3\% BTEX.. SM1 contained (per liter of distilled water): $23 \mathrm{~g} \mathrm{NaC} 1,0.75 \mathrm{~g} \mathrm{KCl}, 1.47 \mathrm{~g} \mathrm{CaCl}_{2} \cdot 2 \mathrm{H}_{2} \mathrm{O}, 5.08 \mathrm{~g}$ $\mathrm{MgCl}_{2} .6 \mathrm{H}_{2} \mathrm{O}, 6.16 \mathrm{~g} \mathrm{MgSO}_{4} .7 \mathrm{H}_{2} \mathrm{O}, 0.89 \mathrm{~g} \mathrm{Na}_{2} \mathrm{HPO}_{4} .2 \mathrm{H}_{2} \mathrm{O}, 5.0 \mathrm{~g} \mathrm{NaNO}_{3}$ and $0.03 \mathrm{~g} \mathrm{FeSO}_{4}$. 
$7 \mathrm{H}_{2} \mathrm{O}$. To prevent precipitation, four separate solutions were prepared and later mixed together after autoclaving when the solutions had cooled to room temperature; the first solution contained $\mathrm{Na}_{2} \mathrm{HPO}_{4}$ and $\mathrm{NaNO}_{3}$ (the $\mathrm{pH}$ value of medium was adjusted to 7.5 by the addition of a $10 \%$ solution of $\mathrm{NaOH}$ ), the second solution contained $\mathrm{NaCl}, \mathrm{KCl}$ and $\mathrm{CaCl}_{2}$, the third solution contained $\mathrm{MgCl}_{2}$ and $\mathrm{MgSO}_{4}$, and the fourth solution contained $\mathrm{FeSO}_{4}$. Bacto agar (Difco, Fisher Scientific, Mississauga, Ontario) $(15 \mathrm{~g} / \mathrm{L})$ was added to the first solution for the preparation of solid media [15]. About 3\% (v/v) and 10\% of sub-cultures were used to inoculate the different media which contained the same carbon source $(3 \%(\mathrm{v} / \mathrm{v})$ of hexadecane, $3 \%(\mathrm{v} / \mathrm{v})$ of motor oil or $3 \%(\mathrm{v} / \mathrm{v})$ of BTEX) as a sole source of carbon and energy. For Colony Forming Units per $\mathrm{mL}(\mathrm{CFU} / \mathrm{mL})$, the solution was serially diluted and plated on agar medium plates which was incubated for $72 \mathrm{~h}$ at $30^{\circ} \mathrm{C}[23]$.

For enzymes recovery, the bacterial culture was centrifuged at $12,000 \mathrm{x}$ g for 30 minutes at 4 ${ }^{\circ} \mathrm{C}$, and the supernatant containing the extracellular enzymes was recovered and stored at -20

${ }^{\circ} \mathrm{C}$ for further biodegradation experiments. A. borkumensis cell pellet $(1 \mathrm{~g})$ frozen at $-20{ }^{\circ} \mathrm{C}$ was re-suspended in phosphate buffer $(1 \mathrm{~mL}, 0.1 \mathrm{M}, \mathrm{pH} 8.0)$. The mixture was sonicated by using two frequencies of ultrasounds $(22 \mathrm{kHz}$ and $30 \mathrm{kHz})$ for 6 min at $4{ }^{\circ} \mathrm{C}$ and centrifuged at $12000 \times \mathrm{g}$ for $30 \mathrm{~min}$. The supernatant was used as a crude intracellular enzyme extract.

\subsection{Biodegradation using the crude enzymes mixture}

The performance of the extracellular and intracellular crude enzymes from A. borkumensis was evaluated in batch tests in Milli-Q water. The test solutions contained $50 \mathrm{~mL}$ Milli-Q water, $10 \mathrm{mg} / \mathrm{mL}$ of an equal mixture of intracellular and extracellular crude enzyme and the different petroleum hydrocarbons concentrations: 5000, 6000 and $7000 \mathrm{mg} / \mathrm{L}$ of hexadecane, $30 \mathrm{mg} / \mathrm{L}, 50 \mathrm{mg} / \mathrm{L}$ and $70 \mathrm{mg} / \mathrm{L}$ of BTEX compounds mixture (1:1:1:1:1:1), 500, 750 and $1000 \mathrm{mg} / \mathrm{L}$ of motor oil, and 2000, 4000 and $6000 \mathrm{mg} / \mathrm{mL}$ of contaminated soil. The control tests are only composed of Milli-Q water at different concentrations of the different substrates 
without the enzyme mixture. The solutions were incubated at $30{ }^{\circ} \mathrm{C}$ for 7 days with shaking at $100 \mathrm{rpm}$ in an incubator shaker. All experiments were carried out in triplicates.

\subsection{Sampling strategy and parameters assayed}

At the beginning $\left(\mathrm{T}_{0}\right)$ and at the end $\left(\mathrm{T}_{7}\right)$ of the experimental period, sub-samples of enzymatic degradation were taken. Measures of enzymes activities (alkane hydroxylase, lipase and esterase) and concentrations of different petroleum hydrocarbons (hexadecane, BTEX and motor oil) were carried out. All experiments were performed in triplicates.

\subsection{Proteins and enzymatic assays}

\subsubsection{Total protein assay}

Both intracellular and extracellular protein concentration were determined according to the Bradford method [24], and the specific activity (units per mg of proteins) for both the intracellular and the extracellular enzymes was determined. .

\subsubsection{Alkane hydroxylase assay}

Alkane hydroxylase activity was measured at $25^{\circ} \mathrm{C}$ using a cofactor (NADPH) depletion assay to determine relative activities. The intracellular enzyme was diluted into phosphate buffer (0.1 M, pH 8), substrate (0.5-1 mM), and dimethyl sulfoxide (DMSO; 1\%, vol/vol). Substrates were added to the buffer using stock solutions in DMSO. The reaction was initiated by addition of NADPH $(200 \mu \mathrm{M})$, and the oxidation of NADPH was monitored at $340 \mathrm{~nm}$ (Glieder et al., 2002). One unit is defined as the amount of enzyme required for consumption of $1 \mu \mathrm{mol}$ of NADPH per min. Hexadecane, BTEX and motor oil were used as substrates.

\subsubsection{Lipaseassay}

Extracellular lipase activity was performed by titrimetric method according to Lopes et al. [25] by using an olive oil emulsion composed of $25 \mathrm{~mL}$ of olive oil and $75 \mathrm{~mL}$ of $7 \%$ Arabic gum solution which was emulsified in liquefier for 2 minutes. About $5 \mathrm{ml}$ of olive oil emulsion was then added to $0.1 \mathrm{M}$ phosphate buffer $(\mathrm{pH} 7.0)$ and $1 \mathrm{~mL}$ of the enzymatic 
suspension $(10 \mathrm{mg} / \mathrm{mL})$ and incubated at $37^{\circ} \mathrm{C}$ for 30 minutes under shaking. Subsequently, the emulsion was immediately disrupted by the addition of $15 \mathrm{~mL}$ of a mixture of acetoneethanol $(1: 1 \mathrm{v} / \mathrm{v})$. The released fatty acids were titrated with $0.05 \mathrm{M} \mathrm{NaOH}$. One unit of lipase activity was defined as the amount of enzyme which liberated $1 \mu \mathrm{mol}$ of fatty acids per minute.

\subsubsection{Esterase assay}

Extracellular esterase activity was measured by titrimetric method according to Lopes et al. [25] by using olive oil as a substrate. The reaction mixture is composed of: $5 \mathrm{~mL}$ of olive oil, $2 \mathrm{~mL}$ of $0.1 \mathrm{M}$ phosphate buffer $(\mathrm{pH} 7.0)$ and $1 \mathrm{~mL}$ of the enzymatic extract $(10 \mathrm{mg} / \mathrm{mL})$. The mixture was incubated at $37{ }^{\circ} \mathrm{C}$ for 30 minutes under shaking and it was immediately disrupted by adding $15 \mathrm{~mL}$ of acetone-ethanol mixture $(1: 1 \mathrm{v} / \mathrm{v})$. The released fatty acids were titrated with $0.05 \mathrm{M} \mathrm{NaOH}$. One unit of esterase activity was defined as the amount of enzyme which liberated $1 \mu \mathrm{mol}$ of fatty acids per minute.

\subsection{Gas chromatography}

GC analysis of petroleum hydrocarbons biodegradation was performed using Hewlett-Packard $6890 / 5973$ with flame ionization detector (FID). Analyses were carried out with helium as the carrier gas at a flow rate of $2 \mathrm{~mL} / \mathrm{min}$ on a DB-1 column $(30 \mathrm{~m}, 0.53 \mathrm{~mm}$ i.d., $1.0 \mathrm{~mm}$ film thickness). Oven temperature was programmed from $60{ }^{\circ} \mathrm{C} 260{ }^{\circ} \mathrm{C}$ at a rate of $4{ }^{\circ} \mathrm{C} / \mathrm{min}$. Split/Splitless injector and detector (FID) temperatures were $260{ }^{\circ} \mathrm{C}$ and $260{ }^{\circ} \mathrm{C}$, respectively, and $1 \mathrm{~mL}$ of the sample was injected [26].

\subsection{Statistical analysis}

All the experiments were performed in replicates and an average of 3 replicates was calculated along with the standard deviation. 


\section{Results and discussion}

\subsection{Dynamics of petroleum hydrocarbons degradation with crude enzymes}

The present study deals with the enzymatic degradation of $A$. borkumensis which was grown in the presence of xenobiotic petroleum hydrocarbons being reported to be toxic substances, such as hexadecane, motor oil and BTEX. Overall, degrading capacities of crude enzymes produced were also tested in the presence of contaminated soil which contains a range of contaminants as described in Table 1.The bacterial strain was able to use the various tested substrates as sole carbon source and energy for its growth and proliferation which was confirmed by cell count. Fig. 1 shows that the cell number reached $4.2 \times 10^{8} \mathrm{CFU} / \mathrm{mL}$ and 8.4 $\mathrm{x} 10^{8} \mathrm{CFU} / \mathrm{mL}$ in the case of hexadecane with $3 \%$ and $10 \%(\mathrm{v} / \mathrm{v})$ inoculum, respectively. In the case of BTEX, the cell count reached $3.7 \times 10^{8} \mathrm{CFU} / \mathrm{mL}$ and $8.9 \times 10^{8} \mathrm{CFU} / \mathrm{mL}$ with $3 \%$ and $10 \%(\mathrm{v} / \mathrm{v})$ inoculum, respectively. And finally in the case of motor oil, the cell count was 7.1x $10^{8} \mathrm{CFU} / \mathrm{mL}$ and $13 \times 10^{8} \mathrm{CFU} / \mathrm{mL}$ with $3 \%$ and $10 \%(\mathrm{v} / \mathrm{v})$ inoculum, respectively. The crude enzyme was isolated after 72 hours of bacterial growth.

Enzymatic degradation can be affected by many parameters, such as the hydrocarbons present in the contaminated site, the concentration of the pollutant, the environmental compartment in which the process is being carried out and the enzymes adaptation $[27,28] .$. In the current study the influence of substrate concentration on the degradation rate of A. borkumensis, was very representative. Herein, the percentage of removal was correlated with the concentration of hydrocarbons and with the specific activity of each of the studied enzymes over time period.

Hexadecane used in this study is part of the aliphatic fraction of crude oil and it is one of the most important components of diesel [29]. This compound is present at many oilcontaminated sites and its biodegradability has been well characterized [30]. For these reasons, hexadecane is used in this study as a model molecule to study aliphatic hydrocarbon 
biodegradation since it has been always considered as a model [31]. The concentrations adopted in our research $(5000 \mathrm{mg} / \mathrm{L}, 6000 \mathrm{mg} / \mathrm{L}$ and $7000 \mathrm{mg} / \mathrm{L})$ were based on the concentration of C10-C50 that has been found in the characterized contaminated soil (Table S3).

The removal percentage of $\mathrm{C}_{16} \mathrm{H}_{34}$ decreased from $73.75 \%$ to $59.74 \%$ after 7 days of enzymatic degradation, while increasing the concentration of hexadecane from 5000 to 7000 $\mathrm{mg} / \mathrm{L}$ when using $10 \%(\mathrm{v} / \mathrm{v})$ of inoculum concentration. As shown in Fig. 2, the specific activity of alkane hydroxylase, lipase and esterase was quite stable after 7 days of degradation using 7000 ppm hexadecane and 10\% (v/v) inoculum. This specific activity decreased from $73.80,2000,2320 \mathrm{U} / \mathrm{mg}$, respectively after extraction of the crude enzymes (initial activity) to $28.57,1628,1781.48 \mathrm{U} / \mathrm{mg}$, respectively after 7 days of degradation. These findings are in agreement with Maletić et al. [32] who reported that hydrocarbon degradation is ultimately dependent on their concentration. Most of the previous studies on hexadecane biodegradation have used an initial concentration lower than $1 \mathrm{~g} / \mathrm{L}$ and have been carried out for up to 45 days [33,34]. Setti et al. [35] reported $86.4 \%$ of hexadecane mineralization at an initial concentration of $12 \mathrm{~g} / \mathrm{L}$ by Pseudomonas sp. after 31 days of biodegradation. Colombo et al. [36] reported that several fungal strains were able to biodegrade up to $80 \%$ of aliphatic hydrocarbons after 90 days, using a contaminated soil with a concentration of $10 \%$ crude oil which contain $16.5 \mathrm{mg}$ of aliphatic hydrocarbons per g of soil. Moreover, Volke-Sepulveda et al. [37] found that an initial concentration of $45 \mathrm{~g} / \mathrm{L}$ of hexadecane was totally mineralized after 31 days of culture using a solid state fermentation.

Moreover as noticed from Fig. 2, the enzyme specific activity considerably increased while increasing the inoculum, from 48, 1642.85, and $1666.66 \mathrm{U} / \mathrm{mg}$ to $73.80,2000$ and $2320 \mathrm{U} / \mathrm{mg}$ for alkane hydroxylase, lipase and esterase, respectively. This increase in enzymes activity had a significant effect on hexadecane degradation. In fact, as observed in Fig. 2, the 
degradation percentage increased almost twice (from 37.70 to 73.75 ) when using $5000 \mathrm{mg} / \mathrm{L}$ of hexadecane and from 32.40 to 38.50 when using $6000 \mathrm{mg} / \mathrm{L}$ of hexadecane and also almost two time degradation increase was observed when using $7000 \mathrm{mg} / \mathrm{L}$ of hexadecane (from 28.31 to 59.74 ), after 7 days of degradation with enzymes produced by the inoculated $A$. borkumensis.

Peng et al. [38] has stated that BTEX mixture is the most toxic TPH component for living cells. The BTEX degradation abilities of the enzymes produced by A. borkumensis inoculated with 3\% (v/v) and 10\% (v/v), were evaluated during 3 days using a BTEX mixture containing $30 \mathrm{mg} / \mathrm{L}, 50 \mathrm{mg} / \mathrm{L}$ and $70 \mathrm{mg} / \mathrm{L}$ of each of the six compounds (benzene, toluene, ethylbenzene, o-xylene, m-xylene and p-xylene $(1: 1: 1: 1: 1: 1))$ in the enzymatic preparation.

As shown in Fig. 2, the initial enzymes activity obtained after extraction from the culture broth with $3 \%(\mathrm{v} / \mathrm{v})$ inoculum measured for the mixture of $70 \mathrm{mg} / \mathrm{L}$ of BTEX were 59.45, 2432.43 and $2928 \mathrm{U} / \mathrm{mg}$ for alkane hydroxylase, lipase and esterase, respectively. The enzyme activity increased to 75, 2785.71 and $3243.24 \mathrm{U} / \mathrm{mg}$ for alkane hydroxylase, lipase and esterase, respectively while increasing the inoculum concentration to $10 \%$ (v/v). Also, as shown in Fig. 3the removal percentage of benzene, ethylbenzene and o-xylene decreased from $72.22 \%, 74.8 \%, 79.3 \%$ to $69.5 \%, 50.25 \%$ and $63.71 \%$, respectively while increasing substrate concentration from $50 \mathrm{mg} / \mathrm{L}$ to $70 \mathrm{mg} / \mathrm{L}$ using $3 \%(\mathrm{v} / \mathrm{v})$ inoculum concentration. However, in the presence of higher inoculum concentration $(10 \%(\mathrm{v} / \mathrm{v}))$, the degradation decreased from $76.48 \%, 71.69 \%, 81.2 \%$ to $71.22 \%, 65.45 \%, 74.8 \%$ respectively.. These observations were in agreement with Li et al. [39] who showed an inhibitory effect of higher benzene concentration (more than $80 \mathrm{mg} / \mathrm{L}$ ) in the presence of Planococcus sp. strain ZD22. Similarly, Hamed et al. [40] reported that specific growth rate of $P$. putida in batch systems has been set up to be a decreasing function of benzene and toluene concentrations. BTEX 
compounds upon reaching certain concentrations can inhibit the microbes and their enzymatic activity due to complex micro- and macro-level interactions [41]. Furthermore, Mathur and Majumber [42] claimed that at higher initial concentrations $(>150 \mathrm{mg} / \mathrm{L}$ benzene and $>200$ $\mathrm{mg} / \mathrm{L}$ toluene), degradation rate was lower. The removal efficiency could also be attributed to the simple structure and the molecular composition of BTEX $[43,44]$. In the case of toluene and as shown in Fig. 3, about $84.22 \%$ of removal percentage was obtained at an initial concentration of $70 \mathrm{mg} / \mathrm{L}$ on day 3 . Thus, toluene had been claimed as the most easily biodegradable among the six compounds of BTEX. In the current study, the mixture of different BTEX compounds (benzene, toluene, ethylbenzene and xylene) together is seen to affect one another. For example, they can interact synergistically or antagonistically as reviewed by Dou et al. [45]. Herein, the interaction between BTEX components in this study seems to be synergistic since a high removal percentage (up to 60\%) is reached while using the mixture of the above contaminants in a time period of 3 days.

Other xenobiotic components were tested in the current study for their removal efficiency, such as motor oil which showed a potential degradation (Fig. 2). As mentioned earlier in this study, this compound was characterized and it is composed of (in mg/L): 69.8 C10-C50, 1.83 naphthalene, $\leq 44$ benzene, $\leq 30$ toluene, $\leq 44$ ethyl-benzene and $\leq 84$ xylene. Thus, $A$. burkumensis grew well on engine oil producing high crude enzymes activities which was confirmed in Fig. 2 by the specific activity of the enzymes. This activity increased from 131.81 to $145.71 \mathrm{U} / \mathrm{mg}$ for alkane hydroxylase and from 3434.78 to $3628.57 \mathrm{U} / \mathrm{mg}$ for lipase and from 2043.47 to $2200 \mathrm{U} / \mathrm{mg}$ for esterase when using $1000 \mathrm{ppm}$ motor oil as substrate and increasing the inoculum concentration. This increase in enzymes activity led to an increase in removal from around $74 \%$ to around $83 \%$ after 7 days of enzymatic degradation. . As discussed earlier, the biodegradation carried out by A. burkumensis seemed to be concentration dependent as observed with BTEX. These results are advantageous compared 
with Pseudomonas aeruginosa which was able to utilize $81 \%$ of used engine oil within 4 weeks compared to 7 days in the current study [46]. Likewise, Basuki et al. [47] reported the removal of 35 out of 47 components of used oil by Acinetobacter junii TBC 1.2. Besides, Pseudomonas aeruginosa LP5 degraded more than $90 \%$ of all oil types within 21 days. The incomplete degradation obtained (between 59-83\%) can be further improved by extending the fermentation time to more than 7 days.

In the current study the degradation efficiency varied largely between the different compounds, hexadecane, BTEX or motor oil reflecting a complexity in the structure and chain-length of the different studied substrates. These observations substantiated the findings of Das and Chandran [48] who stated that all the mechanisms of biodegradation and the degradative enzymes produced are dependent on physical and chemical properties of hydrocarbons.

These results are advantageous compared to similar strains that presented higher degradation capacities. Acinetobacter baumannii isolated from crude oil exhibited $62.8 \%$ of TPH biodegradation after 7 days [49]. Cellulosimicrobium cellulans exhibited hydrocarbon degradability of $18.86 \%$ after 15 days [50]. Similarly, Ijah [51] reported more than 52\% obtained in 16 days.

\subsection{Biodegradation kinetics of contaminated soil}

The crude enzyme used for the degradation of the contaminated soil was produced with $A$. borkumensis using hexadecane as sole carbon source (since it is the standard carbon source). The specific activity obtained during the degradation of $6000 \mathrm{ppm}$ of petroleum hydrocarbons in soil was studied when using both $3 \%$ and $10 \%(\mathrm{v} / \mathrm{v})$ inoculum. In the case of $10 \%(\mathrm{v} / \mathrm{v})$ inoculum and 7 days degradation period, this specific activity decreased from 73.8 to 17.47 U/mg for alkane hydroxylase, from 2000 to $994.26 \mathrm{U} / \mathrm{mg}$ for lipase and from 2320 to 1286 $\mathrm{U} / \mathrm{mg}$ for esterase and it was associated with a high removal percentage reaching $88.52 \%$. The 
higher removal percentage of contaminated soil was observed after 7 days of culture with $64.23 \%, 79.59 \%$ and $88.52 \%$ of degradation calculated with an initial concentration of contaminated soil of $2000 \mathrm{mg} / \mathrm{L}, 4000 \mathrm{mg} / \mathrm{L}$ and $6000 \mathrm{mg} / \mathrm{L}$, respectively. In the $3^{\text {rd }}$ day, $40.67 \%, 54.43 \%$ and $67.29 \%$ were observed with $10 \%(\mathrm{v} / \mathrm{v})$ inoculum in the case of 2000 $\mathrm{mg} / \mathrm{L}, 4000 \mathrm{mg} / \mathrm{L}$ and $6000 \mathrm{mg} / \mathrm{L}$ of contaminated soil, respectively (Fig. 4). This rapid degradation rate on the 3rd day is likely due to the consumption of the easily degradable compounds of low molecular weight found in the soil.

Based on a first order model, degradation constant $(k)$ and half-life $\left(t_{1 / 2}\right)$ were determined. Table 2 presents the kinetic parameters calculated for the removal of TPH in the soil as well as the hydrocarbons consumption data (i.e. global consumption rate; maximum consumption rate). The half-life was around 5.12 days. This indicates that it would take about 10 days to achieve complete biodegradation of the carbon source by applying the tested inoculum and enzymes. According to the analysis, the estimated biodegradation in the soil reached around $64 \%$ of TPH removal. The calculated global consumption rate (GCR) was about $566.14 \pm 42.1$ $\mathrm{mg} \mathrm{kg}^{-1} \mathrm{~d}^{-1}$ for contaminated soil with $6170.7 \mathrm{mg}^{-1} \mathrm{~kg}^{-1}$ of $\mathrm{TPH}$ while the maximum consumption was $363.4 \mathrm{mg}^{-1} \mathrm{~kg}^{-1}$.

Herein, the degradation rate using enzymes from A. borkumensis was very important compared to other reported strains. In fact, Diaz-Ramirez [52] evaluated the biodegradation of hydrocarbons using a bacterial consortium and has found around $62 \%$ of removal within 30 days. In the contaminated soil, the biotransformation of hydrocarbons was probably due to degradation of short chain compounds (low molecular weight) and medium sized alkanes. Herein, the higher content of petroleum hydrocarbons C10-C50 (6020 mg kg$\left.{ }^{-1}\right)$ activated the capacity of biodegradation in the selected microorganism. The biodegradation pathway initially involved the degradation of short to medium chain aliphatics (C10) presented by methyl naphthalene up to $25 \mathrm{mg} \mathrm{kg}^{-1}$. Similarly, Marquez-Rocha et al. (2001), reported the 
degradation of medium sized hydrocarbons (> C12) contained in the diesel, together with the short-chain compounds. To make the process wholesome, ecotoxicological studies should be carried out and special attention should be put on the effects of hydrocarbons on the physicochemical properties of the soil.

\section{Conclusion}

Crude enzyme extracted from Alacanivorax borkumensis showed high efficiency in terms of removal of hydrocarbons. This study confirms the alternative of using bacterial enzymes for the bioremediation of hydrocarbons. High enzymatic activity reaching $145.71 \mathrm{U} / \mathrm{mg}$ for alkane hydroxylase, $3628.57 \mathrm{U} / \mathrm{mg}$ for lipase and $2200 \mathrm{U} / \mathrm{mg}$ for esterase was obtained leading to more than $80 \%$ removal of different compounds with different concentrations namely BTEX, motor oil, hexadecane and contaminated soil, in a short period of time (3 days for BTEX and 7 days for the remaining compounds). Thus, Alacanivorax borkumesis derived enzymes may be used as a powerful approach for the clean-up of environments polluted with petroleum compounds in both aquatic and terrestrial ecosystem.

\section{Acknowledgments}

The authors are sincerely thankful to the Natural Sciences and Engineering Research Council of Canada (Discovery Grant 355254, CRD Grant and Strategic Grant 447075) and TechnoRem Inc. for financial support. The views or opinions expressed in this article are those of the author. 


\section{References}

[1] O. Marchut-Mikolajczyk, E. Kwapisz, D. Wieczorek, T. Antczak, Biodegradation of diesel oil hydrocarbons enhanced with Mucor circinelloides enzyme preparation, Int. Biodeterior. Biodegrad. 104 (2015) 142-148.

[2] M.L. Nievas, M.G. Commendatore, J.L. Esteves, V. Bucalá, Biodegradation pattern of hydrocarbons from a fuel oil-type complex residue by an emulsifier-producing microbial consortium, J. Hazard. Mater. 154 (2008) 96-104.

[3] T.J. McGenity, Hydrocarbon biodegradation in intertidal wetland sediments, Curr. Opin. Biotechnol. 27 (2014) 46-54.

[4] E.Z. Ron, E. Rosenberg, Enhanced bioremediation of oil spills in the sea, Curr. Opin. Biotechnol. 27 (2014) 191-194.

[5] A. Hara, K. Syutsubo, S. Harayama, Alcanivorax which prevails in oil-contaminated seawater exhibits broad substrate specificity for alkane degradation, Environ. Microbiol. 5 (2003) 746-753.

[6] M.M. Yakimov, K.N. Timmis, P.N. Golyshin, Obligate oil-degrading marine bacteria, Curr. Opin. Biotechnol. 18 (2007) 257-266.

[7] L. Wang, W. Wang, Q. Lai, Z. Shao, Gene diversity of CYP153A and AlkB alkane hydroxylases in oil-degrading bacteria isolated from the Atlantic Ocean, Environ. Microbiol. 12 (2010) 1230-1242.

[8] W. Wang, L. Wang, Z. Shao, Diversity and abundance of oil-degrading bacteria and alkane hydroxylase (alkB) genes in the subtropical seawater of Xiamen Island, Microb. Ecol. 60 (2010) 429-439.

[9] C. Liu, W. Wang, Y. Wu, Z. Zhou, Q. Lai, Z. Shao, Multiple alkane hydroxylase systems in a marine alkane degrader, Alcanivorax dieselolei B-5, Environ. Microbiol. 13 (2011) 11681178.

[10] Y. Wu, Y. Teng, Z. Li, X. Liao, Y. Luo, Potential role of polycyclic aromatic hydrocarbons (PAHs) oxidation by fungal laccase in the remediation of an aged contaminated soil, Soil Biol. Biochem. 40 (2008) 789-796.

[11] P.N. Golyshin, V.A.P. Martins Dos Santos, O. Kaiser, M. Ferrer, Y.S. Sabirova, H. Lünsdorf, T.N. Chernikova, O.V. Golyshina, M.M. Yakimov, A. Pühler, K.N. Timmis, Genome sequence completed of Alcanivorax borkumensis, a hydrocarbon-degrading bacterium that plays a global role in oil removal from marine systems, J. Biotechnol. 106 (2003) 215-220. doi:10.1016/j.jbiotec.2003.07.013.

[12] D.J. Naether, S. Slawtschew, S. Stasik, M. Engel, M. Olzog, L.Y. Wick, K.N. Timmis, H.J. Heipieper, Adaptation of the Hydrocarbonoclastic Bacterium Alcanivorax borkumensis SK2 to Alkanes and Toxic Organic Compounds: a Physiological and Transcriptomic Approach, Appl. Environ. Microbiol. 79 (2013) 4282-4293. doi:10.1128/AEM.00694-13.

[13] M. Bookstaver, M.P. Godfrin, A. Bose, A. Tripathi, An insight into the growth of Alcanivorax borkumensis under different inoculation conditions, J. Pet. Sci. Eng. 129 (2015) 153-158. doi:10.1016/j.petrol.2015.02.038.

[14] W.-R. Abraham, H. Meyer, M. Yakimov, Novel glycine containing glucolipids from the alkane using bacterium Alcanivorax borkumensis, Biochim. Biophys. Acta BBA - Lipids Lipid Metab. 1393 (1998) 57-62. doi:10.1016/S0005-2760(98)00058-7.

[15] M.M. Yakimov, P.N. Golyshin, S. Lang, E.R. Moore, W.-R. Abraham, H. Lünsdorf, K.N. Timmis, Alcanivorax borkumensis gen. nov., sp. nov., a new, hydrocarbon-degrading and surfactant-producing marine bacterium, Int. J. Syst. Evol. Microbiol. 48 (1998) 339-348. 
[16] A.C. Morán, N. Olivera, M. Commendatore, J.L. Esteves, F. Siñeriz, Enhancement of hydrocarbon wastebiodegradation by addition of a biosurfactantfrom Bacillus subtilis 09 , Biodegradation. 11 (2000) 65-71.

[17] S. Schneiker, V.A.M. dos Santos, D. Bartels, T. Bekel, M. Brecht, J. Buhrmester, T.N. Chernikova, R. Denaro, M. Ferrer, C. Gertler, A. Goesmann, O.V. Golyshina, F. Kaminski, A.N. Khachane, S. Lang, B. Linke, A.C. McHardy, F. Meyer, T. Nechitaylo, A. Pühler, D. Regenhardt, O. Rupp, J.S. Sabirova, W. Selbitschka, M.M. Yakimov, K.N. Timmis, F.-J. Vorhölter, S. Weidner, O. Kaiser, P.N. Golyshin, Genome sequence of the ubiquitous hydrocarbon-degrading marine bacterium Alcanivorax borkumensis, Nat. Biotechnol. 24 (2006) 997-1004. doi:10.1038/nbt1232.

[18] W. Wang, Z. Shao, Diversity of flavin-binding monooxygenase genes (almA) in marine bacteria capable of degradation long-chain alkanes, FEMS Microbiol. Ecol. 80 (2012) 523533.

[19] W. Wang, Z. Shao, The long-chain alkane metabolism network of Alcanivorax dieselolei, Nat. Commun. 5 (2014).

http://www.nature.com/ncomms/2014/141212/ncomms6755/full/ncomms6755.html (accessed February 13, 2017).

[20] R.N. Austin, J.T. Groves, Alkane-oxidizing metalloenzymes in the carbon cycle, Metallomics. 3 (2011) 775-787.

[21] G.A.-E. Mahmoud, M.M. Koutb, F.M. Morsy, M.M. Bagy, Characterization of lipase enzyme produced by hydrocarbons utilizing fungus Aspergillus terreus, Eur. J. Biol. Res. 5 (2015) 70-77.

[22] W.E. Federation, A.P.H. Association, others, Standard methods for the examination of water and wastewater, Am. Public Health Assoc. APHA Wash. DC USA. (2005). http://www.just.edu.jo/CoursesAndLabs/ENVIRONMENTAL\%20ANALYTICAL\%20CHEMISTR Y_CHEM734/chem\%20734.doc (accessed October 4, 2016).

[23] A.A. Miles, S.S. Misra, J.O. Irwin, The estimation of the bactericidal power of the blood, Epidemiol. Infect. 38 (1938) 732-749.

[24] M.M. Bradford, A rapid and sensitive method for the quantitation of microgram quantities of protein utilizing the principle of protein-dye binding, Anal. Biochem. 72 (1976) 248-254.

[25] D.B. Lopes, L.P. Fraga, L.F. Fleuri, G.A. Macedo, Lipase and esterase: to what extent can this classification be applied accurately?, Food Sci. Technol. Camp. 31 (2011) 603-613.

[26] H.-W. Ryu, Y.-H. Joo, Y.-J. An, K.-S. Cho, Isolation and characterization of psychrotrophic and halotolerant Rhodococcus sp. YHLT-2, J. Microbiol. Biotechnol. 16 (2006) 605-612.

[27] R. Singh, S.M. Celin, Biodegradation of BTEX (benzene, toluene, ethyl benzene and xylene) compounds by bacterial strain under aerobic conditions, J. Ecobiotechnology. 2 (2010). http://scienceflora.org/journals/index.php/jebt/article/view/57 (accessed November 15, 2016).

[28] E. Bamard, C. Bulle, L. Deschênes, Method development for aquatic ecotoxicological characterization factor calculation for hydrocarbon mixtures in life cycle assessment, Environ. Toxicol. Chem. 30 (2011) 2342-2352.

[29] M.R. Chénier, D. Beaumier, R. Roy, B.T. Driscoll, J.R. Lawrence, C.W. Greer, Impact of seasonal variations and nutrient inputs on nitrogen cycling and degradation of hexadecane by replicated river biofilms, Appl. Environ. Microbiol. 69 (2003) 5170-5177.

[30] D.W. Graham, V.H. Smith, D.L. Cleland, K.P. Law, Effects of nitrogen and phosphorus supply on hexadecane biodegradation in soil systems, Water. Air. Soil Pollut. 111 (1999) 118. 
[31] O. Schoefs, M. Perrier, R. Samson, Estimation of contaminant depletion in unsaturated soils using a reduced-order biodegradation model and carbon dioxide measurement, Appl. Microbiol. Biotechnol. 64 (2004) 53-61.

[32] S. Maletić, B. Dalmacija, S. jan Rončević, Petroleum Hydrocarbon Biodegradability in SoilImplications for Bioremediation, Ed. Vladimir Kutcherov. (2013) 43.

[33] J.R. Haines, M. Alexander, Microbial degradation of high-molecular-weight alkanes, Appl. Microbiol. 28 (1974) 1084.

[34] A.O. Hanstveit, Biodegradability of petroleum waxes and beeswax in an adapted $\mathrm{CO} 2$ evolution test, Chemosphere. 25 (1992) 605-620.

[35] L. Setti, G. Lanzarini, P.G. Pifferi, G. Spagna, Further research into the aerobic degradation of $n$-alkanes in a heavy oil by a pure culture of a Pseudomonas sp, Chemosphere. 26 (1993) 1151-1157.

[36] J.C. Colombo, M. Cabello, A.M. Arambarri, Biodegradation of aliphatic and aromatic hydrocarbons by natural soil microflora and pure cultures of imperfect and lignolitic fungi, Environ. Pollut. 94 (1996) 355-362.

[37] T.L. Volke-Sepulveda, M. Gutiérrez-Rojas, E. Favela-Torres, Biodegradation of hexadecane in liquid and solid-state fermentations by Aspergillus niger, Bioresour. Technol. 87 (2003) 81-86.

[38] C. Peng, J.-W. Lee, H.T. Sichani, J.C. Ng, Toxic effects of individual and combined effects of BTEX on Euglena gracilis, J. Hazard. Mater. 284 (2015) 10-18.

[39] H. Li, Y.H. Liu, N. Luo, X.Y. Zhang, T.G. Luan, J.M. Hu, Z.Y. Wang, P.C. Wu, M.J. Chen, J.Q. Lu, Biodegradation of benzene and its derivatives by a psychrotolerant and moderately haloalkaliphilic Planococcus sp. strain ZD22, Res. Microbiol. 157 (2006) 629-636.

[40] T.A. Hamed, E. Bayraktar, T. Mehmetoğlu, Ü. Mehmetoğlu, Substrate interactions during the biodegradation of benzene, toluene and phenol mixtures, Process Biochem. 39 (2003) 27-35.

[41] M.-S. Jo, E.R. Rene, S.-H. Kim, H.-S. Park, An analysis of synergistic and antagonistic behavior during BTEX removal in batch system using response surface methodology, J. Hazard. Mater. 152 (2008) 1276-1284.

[42] A.K. Mathur, C.B. Majumder, Kinetics modelling of the biodegradation of benzene, toluene and phenol as single substrate and mixed substrate by using Pseudomonas putida, Chem. Biochem. Eng. Q. 24 (2010) 101-109.

[43] P.M. Fedorak, D.W.S. Westlake, Degradation of aromatics and saturates in crude oil by soil enrichments, Water. Air. Soil Pollut. 16 (1981) 367-375.

[44] A. Horowitz, R.M. Atlas, Response of microorganisms to an accidental gasoline spillage in an arctic freshwater ecosystem, Appl. Environ. Microbiol. 33 (1977) 1252-1258.

[45] J. Dou, X. Liu, Z. Hu, Substrate interactions during anaerobic biodegradation of BTEX by the mixed cultures under nitrate reducing conditions, J. Hazard. Mater. 158 (2008) 264-272.

[46] R. Thenmozhi, A. Nagasathya, N. Thajuddin, Studies on biodegradation of used engine oil by consortium cultures, Adv. Environ. Biol. (2011) 1051-1058.

[47] W. Basuki, K. Syahputra, A.T. Suryani, I. Pradipta, Biodegradation of Used Engine Oil by Acinetobacter junii TBC 1.2, Indones. J. Biotechnol. 16 (2015). http://journal.ugm.ac.id/ijbiotech/article/view/7845 (accessed March 13, 2017).

[48] N. Das, P. Chandran, Microbial degradation of petroleum hydrocarbon contaminants: an overview, Biotechnol. Res. Int. 2011 (2010). http://www.hindawi.com/journals/btri/2011/941810/abs/ (accessed March 27, 2015). 
[49] S. Mishra, P.M. Sarma, B. Lal, Crude oil degradation efficiency of a recombinant Acinetobacter baumannii strain and its survival in crude oil-contaminated soil microcosm, FEMS Microbiol. Lett. 235 (2004) 323-331.

[50] B.M. Nkem, N. Halimoon, F.M. Yusoff, W.L.W. Johari, M.P. Zakaria, S.R. Medipally, N. Kannan, Isolation, identification and diesel-oil biodegradation capacities of indigenous hydrocarbon-degrading strains of Cellulosimicrobium cellulans and Acinetobacter baumannii from tarball at Terengganu beach, Malaysia, Mar. Pollut. Bull. 107 (2016) 261268.

[51] U.J.J. ljah, Studies on relative capabilities of bacterial and yeast isolates from tropical soil in degrading crude oil, Waste Manag. 18 (1998) 293-299. doi:10.1016/S0956053X(98)00037-3.

[52] I.J. Díaz-Ramírez, Biodegradación de hidrocarburos por un consorcio microbia-no de la rizósfera de una planta nativa de pantano, Tesis de Maestría, Universidad Autónoma Metropolitana-Iztapalapa, México, 2000. 


\section{Figures}

\section{Figure Captions:}

Fig. 1: Colony forming units per $\mathrm{mL}$ of Alcanivorax borkumensis using different substrates and inoculated with (a) $3 \%(\mathrm{v} / \mathrm{v})$ and (b) $10 \%(\mathrm{v} / \mathrm{v})$.

Fig. 2: Specific enzyme activity and removal percentage of different petroleum hydrocarbons using the crude enzyme produced by $A$. borkumensis at different inoculum size $3 \%$ (v/v) (not scratched histograms) and 10\% (v/v) (scratched histograms).

Fig. 3: Removal percentage of different BTEX compounds during 3 days using the crude enzyme produced by $A$. borkumensis at different inoculum size 3\% (v/v) (not scratched histograms) and 10\% (v/v) (scratched histograms).

Fig. 4: Specific enzyme activity and removal percentage of petroleum hydrocarbons in the soil using the crude enzyme produced by A. borkumensis at different inoculum size $3 \%(\mathrm{v} / \mathrm{v})$ (not scratched histograms) and 10\% (v/v) (scratched histograms). 

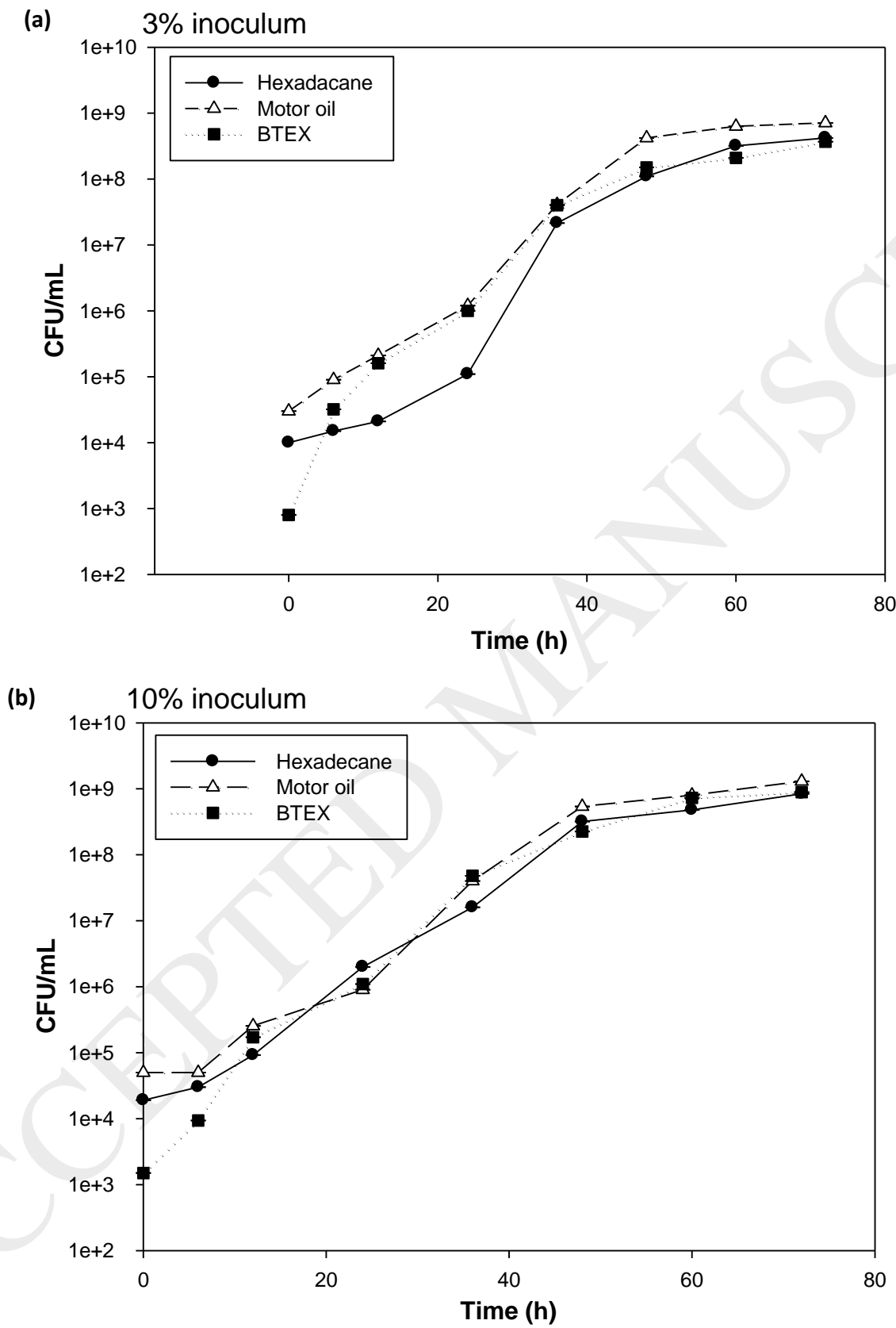

Fig. 1: Colony forming units per $\mathrm{mL}$ of Alcanivorax borkumensis using different substrates and inoculated with (a) $3 \%(\mathrm{v} / \mathrm{v})$ and (b) $10 \%(\mathrm{v} / \mathrm{v})$. 
(a)

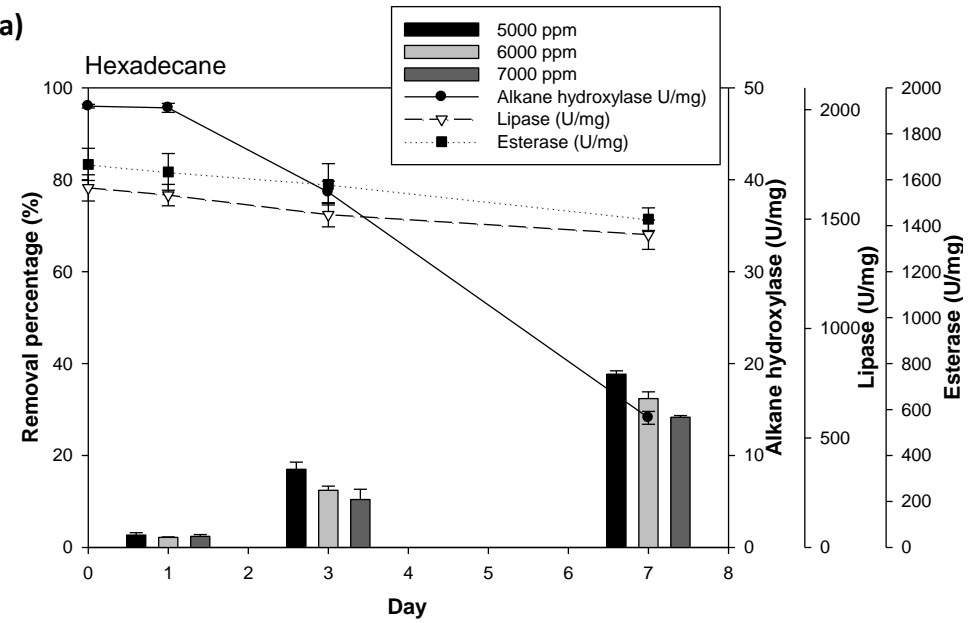

(c)

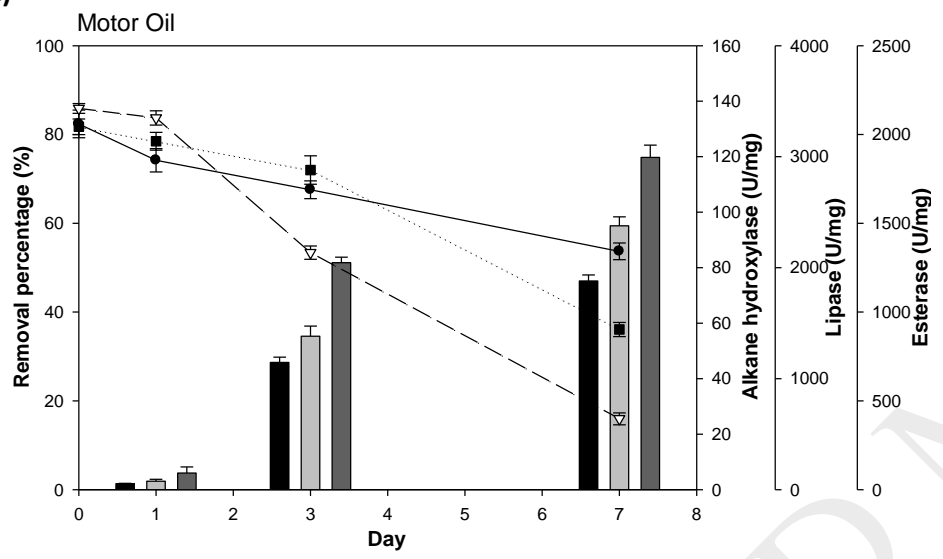

(e)

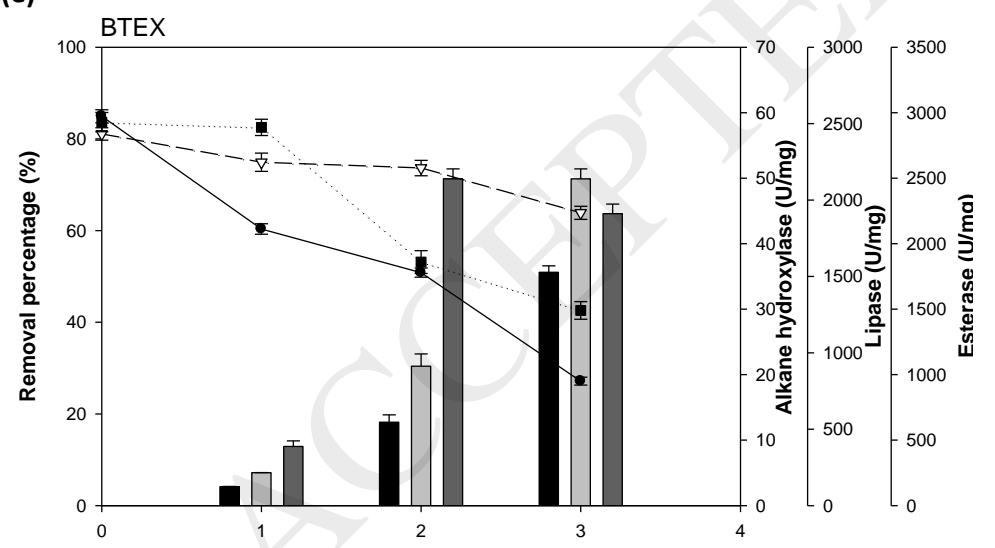

(b)

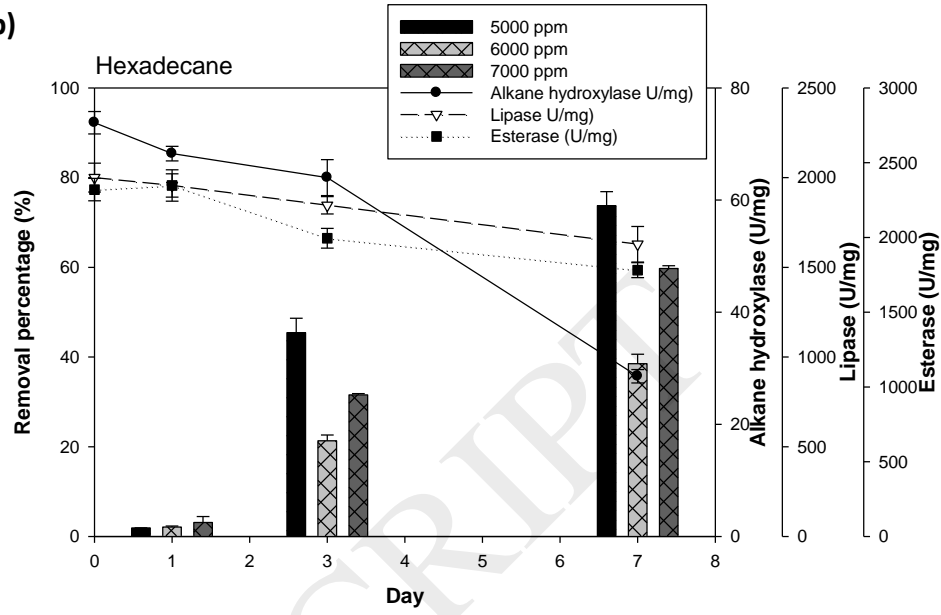

(d)

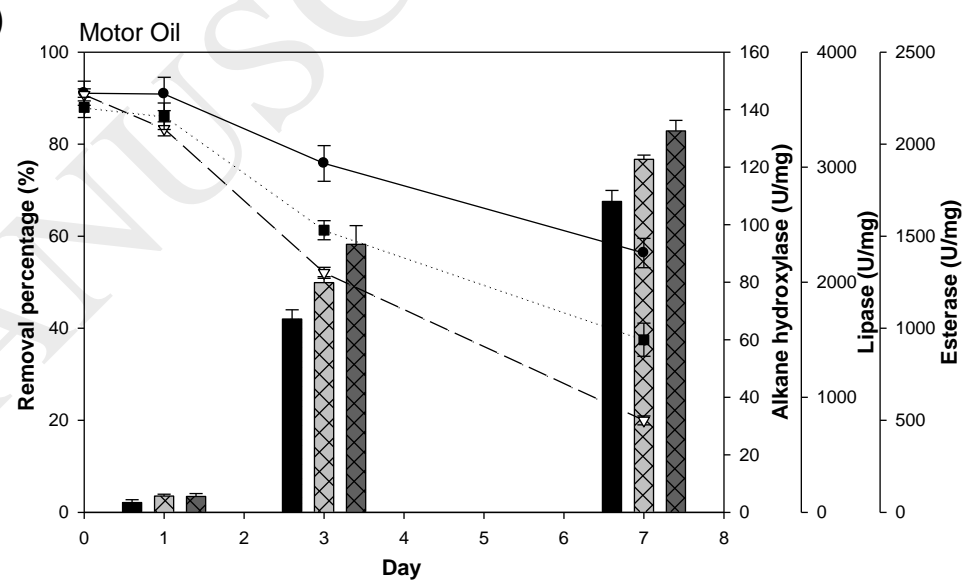

(f)

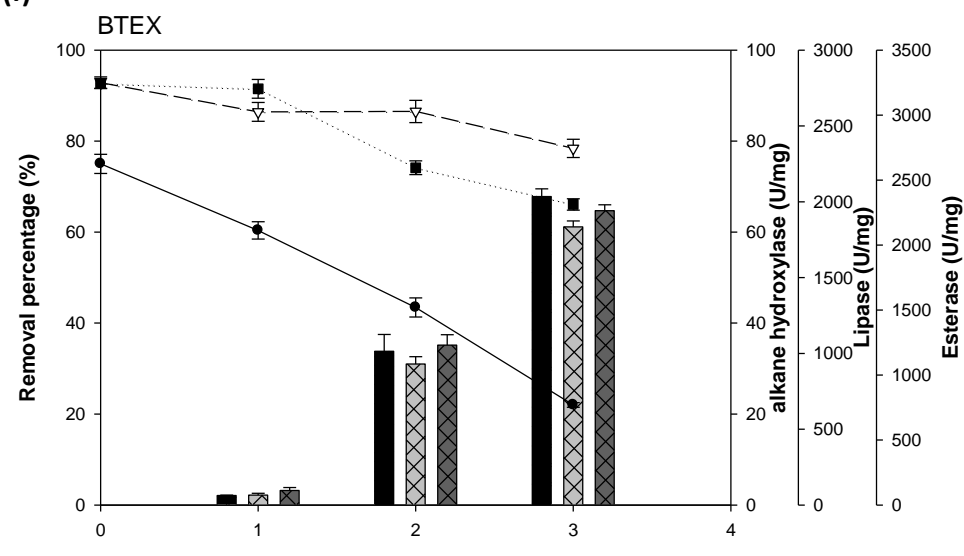

Day

Fig. 2: Specific enzyme activity and removal percentage of different petroleum hydrocarbons using the crude enzyme produced by A. borkumensis at different inoculum size 3\% (v/v) (not scratched histograms) and 10\% (v/v) (scratched histograms). 

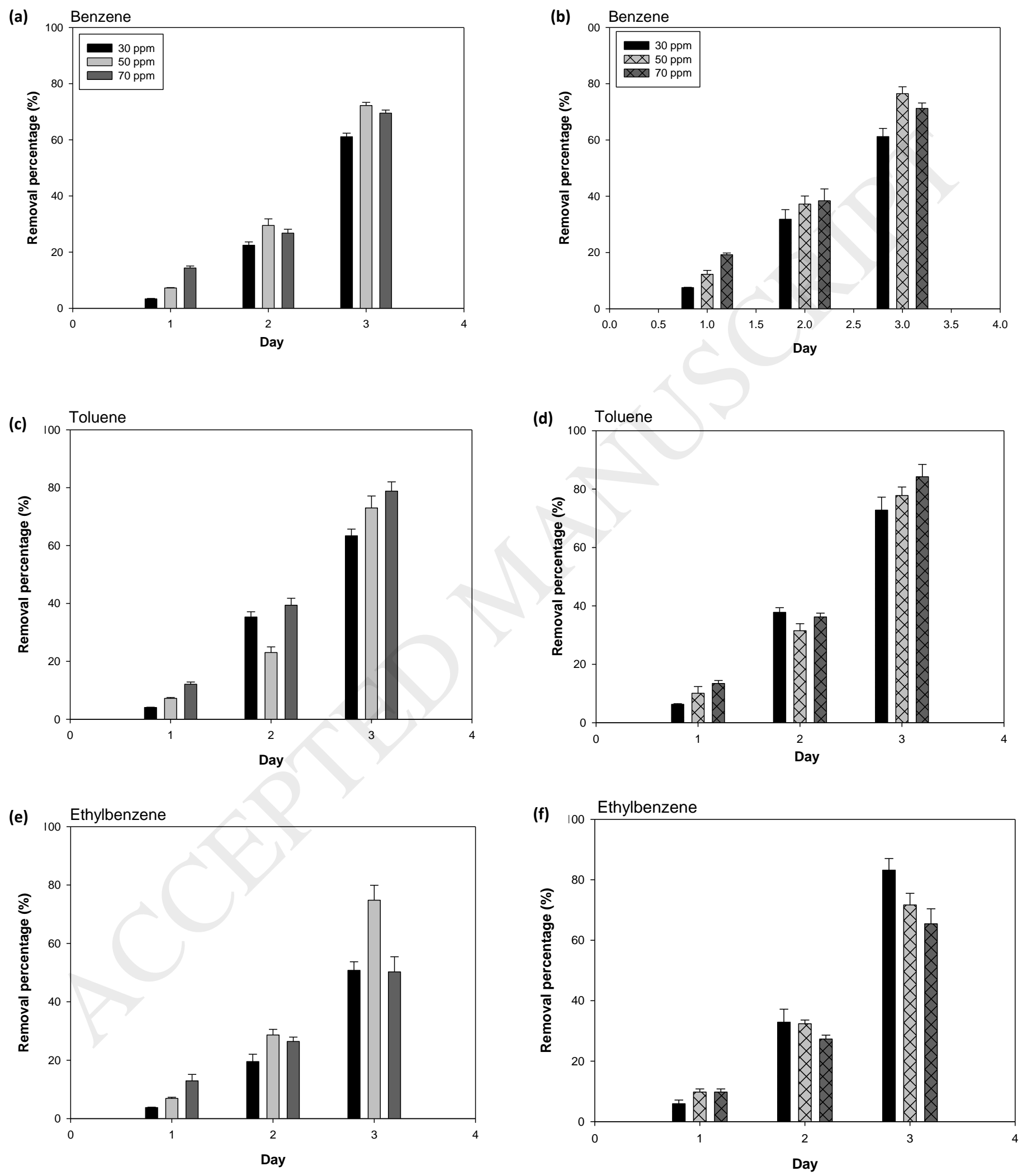

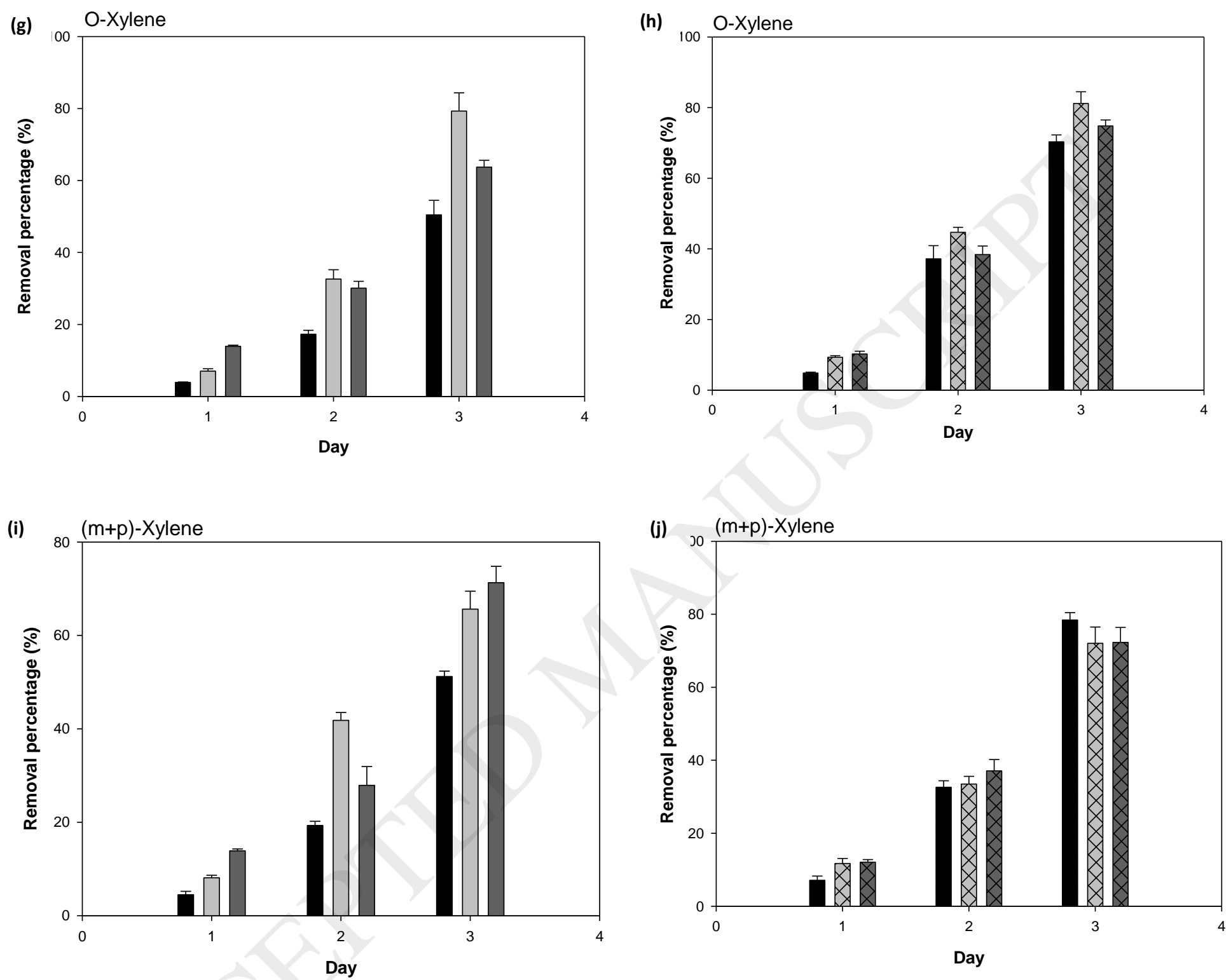

Fig. 3: Removal percentage of different BTEX compounds during 3 days using the crude enzyme produced by $A$. borkumensis at different inoculum size 3\% (v/v) (not scratched histograms) and 10\% (v/v) (scratched histograms). 
Tables

\begin{tabular}{|c|c|c|c|}
\hline Parameters & Units & Soil & Soluble fraction \\
\hline Total solids & $\%$ & $75.36 \pm 0.93$ & - \\
\hline Moisture content & $\%$ & $24.17 \pm 0.45$ & \\
\hline $\mathrm{pH}$ & - & $7.80 \pm 0.10$ & - \\
\hline Density & g.cm ${ }^{-3}$ & $1.15 \pm 0.02$ & - \\
\hline Total carbon $(\mathrm{C})$ & $\mathrm{gC} / 100 \mathrm{~g}$ & $0.38 \pm 0.02$ & $98.00 \mathrm{mg} / \mathrm{L}$ \\
\hline Total nitrogen $(\mathrm{N})$ & $\mathrm{gN} / 100 \mathrm{~g}$ & $0.06 \pm 0.002$ & $1.61 \mathrm{mg} / \mathrm{L}$ \\
\hline $\mathrm{C} / \mathrm{N}$ ratio & - & 6.33 & - \\
\hline Oil content & $\%$ & $13.87 \pm 0.81$ & - \\
\hline
\end{tabular}

Table 1: Soil characteristics.

Table 2: Biodegradation constant and half-life for total petroleum hydrocarbons removal in soil, after 7 days assay.

\begin{tabular}{|c|c|c|c|c|c|}
\hline & $\begin{array}{l}\text { Biodegradation } \\
(\%)\end{array}$ & $\begin{array}{l}\text { GCR }^{\mathrm{a}} \\
\left(\mathrm{mg} \mathrm{kg}^{-1} \mathrm{~d}^{-1}\right)\end{array}$ & $\begin{array}{l}\operatorname{MCR}^{\mathrm{b}} \\
\left(\mathrm{mg} \mathrm{kg}^{-1} \mathrm{~d}^{-1}\right)\end{array}$ & $\begin{array}{l}k^{c} \\
\left(d^{-1}\right)\end{array}$ & $\begin{array}{l}\text { Half life time } \\
\text { (day) }\end{array}$ \\
\hline Contaminated soil & $64.23 \pm 0.45$ & $566.14 \pm 42.10$ & $363.40 \pm 32.50$ & 0.16 & 5.12 \\
\hline \multicolumn{6}{|c|}{${ }^{a}$ Global Consumption Rate (GCR) was calculated considering the initial and residual } \\
\hline \multicolumn{6}{|c|}{ hydrocarbon content after 7 days. } \\
\hline${ }^{\mathrm{b}}$ Maximum Consur & ption Rate (MCR). & & & & \\
\hline
\end{tabular}




$$
C=C_{0} e^{-k t}
$$

Where:

$C=$ Total petroleum hydrocarbon concentration at " $t$ " time

$C_{0}=$ Initial concentration of petroleum hydrocarbon

$k=$ Biodegradation constant represented as the slope of the $L n C / C_{0} v s$ time (days).

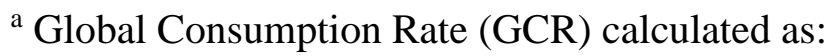

$$
G C R=\frac{\left[T P H_{\text {final }}\right]-\left[T P H_{\text {initial }}\right]}{t_{0}-t_{\text {final }}}
$$

Where:

GCR: Global consumption rate

$T P H_{\text {final }}=$ Total petroleum hydrocarbon concentration at the end of the assay

$T P H_{\text {inital }}=$ Initial total petroleum hydrocarbon concentration

$t_{0}=$ initial time

$t_{\text {final }}=$ final experimental time

${ }^{\mathrm{b}}$ Maximum Consumption Rate (MCR) calculated as:

$$
M C R=\frac{[T P H r]_{n}-[T P H r]_{n-1}}{t_{n-1}-t_{n}}
$$

Where:

MCR: Maximum consumption rate determined between each sampling interval $\left[\mathrm{TPH}_{r}\right]_{n}=$ Residual total petroleum hydrocarbon concentration at $t n$ $\left[\mathrm{TPH}_{r}\right]_{n-1}==$ Residual total petroleum hydrocarbon concentration at $t n-1$ 